health reform strategies. Besides, the effect of AIDS on infant mortality is not significant ${ }^{19}$ Furthermore, other countries that are also experiencing a protracted civil war, such as Sri Lanka, have maintained good social welfare through a non-market based health system. ${ }^{20}$

\section{What can be learnt from the market reform experience?}

Several lessons can be learnt from the market reform experiment. Firstly, market economic principles are good for generating wealth but poor at improving health and social welfare. Secondly, to carry out genuine health sector reforms based on agreed health objectives, the health reforms must be disentangled from market based economic reforms. In particular, governments must guarantee social security and essential health services to all. This means macroeconomic variables should be manipulated to facilitate the attainment of social welfare targets without jeopardising economic growth. This is possible, as countries such as Costa Rica and Sri Lanka have shown..$^{20}$

Thirdly, the market philosophy, which is based on greed and the accumulation of profit, cannot be the proper basis for maximising welfare. Instead, the principles of solidarity and compassion should provide the basis for social welfare. The study of how to achieve maximum health within a given economy should be developed as a separate discipline from market based health economics, which is primarily concerned with minimisation of spending. Fourthly, aid and technical assistance to poor countries must be given and managed in a way that ensures a positive effect on health and social welfare. In the long run, poor countries such as Uganda should adopt a universal health and welfare framework, which they must increasingly finance from internal sources. Lastly, health and welfare must be assessed by using genuine indicators that comprehensively measure the reality of people's lives.

Competing interests: None declared.

World Bank. World development report: investing in health. Oxford: Oxford University Press, 1993.

2 World Bank. Staff appraisal report: district health services pilot and demonstration project. Washington, DC: World Bank, 1994.

\section{Summary points}

Donor agencies increasingly require market based health reforms before giving grants to developing countries

In Uganda market reforms have not improved health care

Inequity in access to health care has increased and important health indicators have worsened

More emphasis needs to placed on social welfare

3 Government of Uganda. Status of emergency obstetric care (EMOC) in Uganda. A national needs assessment of EMOC indicators. Kampala: Ministry of Health, 2003 .

4 Okuonzi SA, Birungi H. Are lessons from the education sector applicable to health sector reforms? The case of Uganda. Int Health Planning Manage 2000;15:201-19

5 Government of Uganda. Mid-term review report of the health sector strategic plan. Kampala: Ministry of Health, 2003.

6 Kiyonga C. Policy statement: abolition of user-charges and introduction of a dual system. Uganda Health Bull 2001;7:No 2.

7 Deininger K, Mpuga P. Economic and welfare impact of the abolition of health user fees: evidence from Uganda. Washington, DC: World Bank, 2004.

8 Brownbridge M. Financing the millennium development goals: is more public spending the best way to meet poverty reduction gals. is more public spending the best way to meet poverty reduction targets? Health Policy Dev 2004;2:40-7.http://bij.hosting.kun.nl/umu/faculty/bam/dhs/
healthpolicy/vol2.html

Uganda Bureau of Statistics, Macro International. Uganda demographic and health survey 2000-2001. Claverton, MD: UBOS, ORC Macro, 2001.

10 Government of Uganda. Poverty eradication action plan: draft. Kampala: Ministry of Finance, Planning and Economic Development, 2004.

11 Government of Uganda. Background to the budget for financial year 2004/2005. Kampala: Ministry of Finance, Planning and Economic Development, 2004.

12 Ocom F. Quality of care in Mukono district-Uganda [Dissertation for MSc in public health]. Kampala: Makerere University, 1997.

13 Jitta J. Ouality of care in Uganda health services in health care systems in Africa. Copenhagen: University of Copenhagen, Enreca Health Copenhagen: Univer

14 Chen S, Ravalllion M. How have the poorest fared since the early 1980s? Chen S, Ravallion M. How have the
Washington DC: World Bank, 2004.

15 Ravallion M. Competing concepts of inequity in the globalization debate. Washington DC: World Bank, 2004.

16 Lindelow M. Sometimes more equal than others: How health inequalities depend on the choice of welfare indicators. Washington, DC: World Bank, Centre for Study of African Economies, Oxford University, 2004.

17 Stigliz J. Globalization and its discontents. London: Penguin Books, 2002.

18 Government of Uganda. Uganda national HIV and AIDS policy:draft. Kampala: Uganda AIDS Commission, 2004.

19 Adetunji J. Trends in child mortality rates and the HIV/AIDS epidemic. Bull World Health Organ 2000;78:1002-6.

20 Abel-Smith B. An introduction to health: policy, planning and financing. London: Longman, 1994.

\title{
Commentary: the devil is in the detail
}

\author{
Martin McKee, Barbara McPake
}

Okuonzi argues that the introduction of market reforms, into the Ugandan health system has been a failure. ${ }^{1}$ However, health systems are extremely complex and, as the debate about the British internal market shows, attribution of cause and effect is far from easy. The situation in Uganda is equally complex, with reforms taking place against a background of regional conflict, growing inequalities, and changes in other sectors. Furthermore, while Okuonzi focuses on hospitals, it is equally important to look at primary care, which the Ugandan reforms have sought to strengthen.
Can we gain insights about market reforms from other low and middle income countries? It is important to distinguish between reforms directed at funding and those directed at delivery of care. Many policies aimed at funding, such as user fees, increase the economic burden on families. This can deter them from seeking necessary care and increases the risk of impoverishment from expenditure on catastrophic illness, ${ }^{2}$ as is now happening in China. ${ }^{\mathrm{w} 1}$

References w1-w6 are on bmj.com
European Centre on Health of Societies in Transition, London School of Hygiene and Tropical Medicine, London WC1E 7HT Martin McKee professor of European public health continued over 


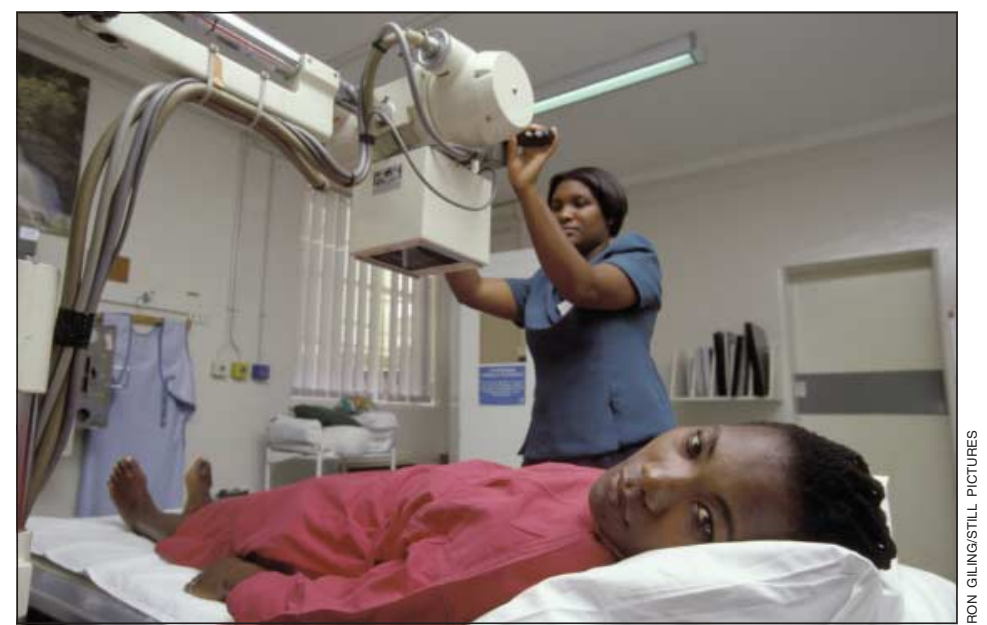

Private hospitals in Zimbabwe have failed to deliver expected savings

Health Systems Development Programme, London School of Hygiene and Tropical Medicine Barbara McPake senior lecturer in health economic

Correspondence to: M McKee Martin.McKee@ Martin.McKe
lshtm.ac.uk
The situation regarding reforms to healthcare delivery is more mixed, although the available evidence is limited and often context specific. One issue is contracting with private providers by public bodies. This offers potential benefits by combining public finance with private provision, but in practice these may not always be realised. ${ }^{3}$ For example, although a privately owned hospital in Zimbabwe offered services of at least as good quality as a nearby government hospital and at lower prices, the private hospital's failure to control admission thresholds allowed costs to increase. $^{\text {w2 }}$ Other research in South Africa and Zimbabwe found that, although costs were lower in private hospitals, any savings were eliminated by the cost of contracting. ${ }^{\mathrm{w} 3}$

A second issue is increased autonomy of providers. This has been successful only when facilities invest in management techniques and training linked to appropriate incentive systems for staff. ${ }^{4}$ Reviews of experience in eastern Europe $^{5}$ and sub-Saharan Africa have identified only modest success in achieving the stated goals of increasing autonomy. ${ }^{6}$

A third issue is the question of public or private provision. Enthusiasm for privatising state facilities, to achieve supposed efficiency gains, is being tempered by a realisation that the evidence is rather mixed. A study of government and non-governmental dispensaries in Tanzania found considerable variation in both sectors. ${ }^{\text {w4 }}$ This finding was replicated in research on primary care providers in the same country; although quality of care was, on average, better in the private providers, much care was of low quality care in both types of facility. ${ }^{\mathrm{w5}}$ Similar results have been obtained from research in Senegal. ${ }^{\mathrm{w6}}$ In summary, little evidence is available to support the contention that private provision is better than public, and what evidence exists indicates that there is often considerable variation in both.

So are market oriented reforms in health care good or bad? There is no simple answer. Much depends on how they are implemented. This is an area where more evidence rather than ideology is needed.

$\mathrm{MM}$ and BM are members of the UK Department for International Development's (DfID) health systems development knowledge programme. DfID accepts no responsibility for the views expressed.

Competing interests: None declared.

1 Okuonzi SA. Learning from failed health reform in Uganda. BMJ 2004:329:1173-5.

2 Xu K, Evans DB, Kawabata K, Zeramdini R, Klavus J, Murray CJ. Household catastrophic health expenditure: a multicountry analysis. Lancet 2003;362:111-7.

3 McPake B, Banda EE. Contracting out of health services in developing countries. Health Policy Plan 1994;9:25-30.

4 Hawkins L, Ham C. Reviewing the case studies: tentative lessons and hypotheses for future testing. In: Preker AS, Harding AL, eds. Innovations in health service delivery: the corporatization of public hospitals. Washington, DC: World Bank, 2003:169-206.

5 Healy J, McKee M. Implementing hospital reform in central and eastern Europe. Health Policy 2002;61:1-19.

6 McPake BI. Public autonomous hospitals in sub-Saharan Africa: trends and issues. Health Policy 1996;35:155-77.

\section{Run with your client, not after}

Chris was always climbing the fence, an eight feet high, chain link structure that surrounded the euphemistic "garden" on three sides. The fourth side faced the three storey, red brick ward that was home of sorts to a dozen people with learning disabilities and challenging behaviour, and half a dozen members of staff. Chris's most prominent behaviour was "absconding from the ward"-the reason for his admission and an activity he engaged in quite successfully on a daily basis.

The escape itself was never witnessed. Chris would fade imperceptibly from the consciousness of the assembled staff and then suddenly reappear running full tilt away from the fence. The staff would then snap into action, our joint and single purpose to catch him and bring him back to within the confines of the fence. However, our prey stood more than six feet tall and, with daily practice, had developed the athleticism and speed of an ostrich. He could change direction in an instant with no evident loss of speed and could slow down and speed up with no suggestion of inertia.

We would break into smaller units and, running at breakneck speed, try to limit the available directions he might take. We would gather volunteers to the chase as if in a stampede. But catching Chris, despite our greater numbers, invariably took upwards of an hour. Pursuers would retire from the chase exhausted; sometimes entire shifts would change during the hunt. Ultimately, however, Chris would be apprehended and, only partially subdued in a ruck of staff, guided back to the ward, where he would be carefully watched for the rest of the day while he returned our gaze as a scowl.

I don't know how it happened, nobody does. Chris had breached the fence again, and somebody went to fetch him back. But this time the mood was completely different, completely at odds with the usual sense of crisis. Perhaps we no longer cared. Perhaps, somehow, we were inspired. Our solitary staff member didn't pursue Chris. He didn't barrel after him like a Pamplona bull. He just ran. Within a few minutes he was shoulder to shoulder with Chris and running alongside. And they kept running. They ran for a further 10 minutes or so and then returned to the ward. Nobody laid a finger on Chris. Nobody said a word. There was a 10 minute run and then home.

There were no escapes after that. Just runs.

Jim Cromwell clinical psychologist, South West London and St George's Mental Health NHS Trust, London 